\title{
E.Coli Analysis of Settlement without Slums in Deli River Watershed, Hamdan Sub-District, Medan Maimun
}

\author{
Rahmadhani Fitri \\ Faculty of Science and Technology, Architecture Eengineering Study Program, Universitas Pembangunan \\ Panca Budi, Indonesia \\ rahmadhanifitri@dosen.pancabudi.ac.id
}

\begin{abstract}
The aim of the study is to find out E.Coli Analysis of Settlement without Slums in Deli River Watershed, Hamdan Sub-District, Medan Maimun. The results shows that E. Colli Laboratory amounting to $21420-36540 / 100 \mathrm{ml}$, still above the quality standards set by PP No.82 of 2001 concerning the management of water quality and control of water pollution. The results of the analysis of Total Coliform Laboratory of 198630 $241960 / 100 \mathrm{ml}$, are still above the quality standards set by PP No.82 of 2001 concerning the management of water quality and control of water pollution. Alternative water treatment needs to be done before structuring buildings around the river location by means of filtration treatment and disinfecting. The arrangement that needs to be done next is to make a bathroom around the river location.
\end{abstract}

Keywords

E.coli; settlement; slums;

Deli river

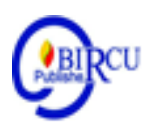

\section{Introduction}

Escherichia coli is a biological indicator of air pollution. The presence of E.Coli in water proves that the water is contaminated by human and animal feces. This is more important than faeces or feces which also contain other pathogenic enteric microorganisms. E.Coli becomes a pathogen if the number of these bacteria increases or is outside the intestine, one of the human digestive systems. Therefore, E.Coli produces enterotoxins which cause several cases of diarrhea (Brookset al., 2004).E. coli is also one of the bacteria from microflora found in the digestive tract of humans and animals. E. coli is a heterotrophic bacterium that obtains food in the form of organic substances from its environment because it cannot compile the organic substances it needs. This organic substance is obtained from the rest of other organisms. E. Colli breaks down organic matter in food into inorganic substances, namely $\mathrm{CO} 2, \mathrm{H} 2 \mathrm{O}$, energy and minerals. In the environment, these spoilage bacteria function as decomposers and provide nutrition for plants (Kusuma, 2010). Transmission of Escherichia coli which causes diarrhea through water polluted from faeces. In addition, transmission also occurs through contact from infected workers while the food is being processed so Escherichia coli can be one of the causes of foodborne disease, which a disease is caused by consuming contaminated food or drinks.

Deli River is one of eight rivers in the city of Medan. Initially, during the Deli kingdom, the river was a vein of trade to other regions. At present, the forest area in the upper reaches of the Deli River is only 3,655 hectares, or only 7.59 percent of the 48,162 hectares of the Deli River Basin area. In fact, with an area of 48,162 hectares, a length of $71.9 \mathrm{~km}$ and a width of $5.58 \mathrm{~km}$, besides that, waste now pollutes the river. Deli River pollution, 70 percent of which is caused by solid and liquid waste. Sungai Deli is now changing its function as a long and wide trash bin. The riverbank community uses the river besides for 
bathing, washing, drinking and cooking, it is also used as a place to urinate and defecate, as well as a place for garbage disposal.

Law Number 1 of 2011 concerning Housing and Settlement Areas states that Slums are non-habitable settlements due to building irregularities, high building density, and the quality of buildings and facilities and infrastructure that do not meet the requirements. The condition of the facilities and infrastructure does not meet the requirements (facilities and infrastructure limits are set within the scope of the craft), namely: Environmental Roads, Environmental Drainage, Water Supply / Drinking, Waste Management, Waste Water Management, Fire Protection

The area of Hamdan settlement is 14.93 hectares while the total area of the village is 52 hectares with a population of 2736 people who have a low-income community of 255 RT / person. The people of Hamdan Yang Village adjoining Deli River have access to family toilets by $38 \%$. This forced the community to dispose of their faeces directly. Although there are some people who use septic tanks, disposal will go directly to the river faster and this will affect the biological indicators of river water pollution, especially E. Coli.

\section{Review of Literature}

\subsection{Clean / Drinking Water Quality Standards}

Minister of Health Decree (Kepmenkes) RI No. 907 / Menkes / SK / VII / 2002 Concerning Requirements and Supervision of Drinking Water Quality, states that drinking water is water that has been processed or has no processing that meets health requirements and can be drunk directly. The types of drinking water include:

a. Water distributed through pipes for household use.

b. Water distributed through water tanks.

c. Bottled water.

d. Water used for the production of food and beverages served to the public.

The four types of drinking water must meet drinking water quality requirements that include physical, chemical, bacteriological and radioactive requirements.

\subsection{Water Treatment Unit}

Water treatment is defined as a technical operation carried out on raw water in order to become clean water that meets the quality requirements as clean water / drinking water by combining several treatment processes. Water treatment aims to reduce the concentration of each pollutant in water so that it is safe to use. According to Reynolds (1982 p. 1) the operating units and process units used in water treatment are as follows:

a. Physical treatment includes sedimentation, flotation and filtration.

b. Chemical processing includes coagulation, flocculation, adsorption, exchange ion and chlorination.

c. Biological treatment includes aerobic digestion and anaerobic sigestion.

Table 1. Some Processing Alternatives

\begin{tabular}{|l|l|l|}
\hline No & Parameter & Alternative processing \\
\hline 1 & \multirow{2}{*}{ Color } & Coagulation \\
\cline { 3 - 3 } & & Rapid Sand Filter \\
\cline { 3 - 3 } & & Adsorption of GAC, PAC, synthetic resins \\
\hline
\end{tabular}




\begin{tabular}{|l|l|l|}
\hline \multirow{2}{*}{2} & Smell And Taste & $\begin{array}{l}\text { Oxidation with chlorine, permanganate and } \\
\text { chlorine dioxide }\end{array}$ \\
\hline 3 & \multirow{2}{*}{ Turbidity } & $\begin{array}{l}\text { Oxidation with chlorine, permanganate and } \\
\text { chlorine dioxide }\end{array}$ \\
\cline { 3 - 3 } & & Active Carbon Adsorption (GAC and PAC) \\
\cline { 3 - 3 } & & BAC adsorption \\
\hline 4 & bacteria, virus* & Preasedimentation (water with high turbidity) \\
\cline { 3 - 3 } & & Filtration \\
\hline
\end{tabular}

Source : Montgomery, 1985; AWWA, 1998(*)

\subsection{Escherichia Coli}

E. coli is a facultative anaerobic Gram-negative bacterium and cannot form spores. This bacterium can live on various substrates by performing anaerobic fermentation to produce lactic acid, succinic, acetic, ethanol, and carbon dioxide (Anonymous 2008) .E. coli belongs to the family Enterobacteriaceae, in the form of a stem or coma, there is a single or paired in a short chain. (Whittam., Et al., 2011). The following E. Coli Classifications are as follows.

Kingdom : Bacteria

Phylum : Proterobacteria

Class : Gamma Proteobacteria

Ordo : : Enterobacteriales

Family : Enterobacteriaceae

Genus : Escherichia

Species : Escherichia coli.(Hardjoeno, 2007)

Bacteria Escherichia coli (E. colli) is a bacterium that lives in the human intestine to maintain the health of the digestive system. These bacteria are generally not harmless. However, there are certain types of E. coli that produce toxins and cause severe diarrhea. A person can be exposed to harmful E. coli bacteria by consuming contaminated food and drinks. Exposure to E. Coli can cause symptoms such as abdominal pain, diarrhea, nausea, and vomiting. The disease caused by E. coli bacteria will have a more severe impact if it occurs in children and the elderly.

a. Causes of Escherichia Coli Bacterial Infection

The presence of E. coli bacteria in the human body is a natural thing, because these bacteria also play a role in maintaining the health of the digestive tract. However, there are several types of E. coli bacteria that are actually harmful to human health, namely:

- Shiga toxin-producing coli atau STEC/VTEC/EHEC

- Enterotoxigenic coli (ETEC).

- Enteropathogenic coli (EPEC).

- Enteroaggregative coli (EAEC).

- Enteroinvasive coli (EIEC).

- Diffusely adherent coli (DAEC). 
Most diarrhea is caused by STEC type bacteria. This bacterium produces toxins that can damage the lining of the small intestine, which can cause bloody bowel movements. In general, the dangerous E. coli bacteria can enter the human body through:

- Contaminated food and drinks

The dangerous E. coli bacteria is highly contagious because a person consumes contaminated food and drinks.

- Direct contact with E. coli bacteria

Forgot to wash your hands after handling an animal or after defecating, then in contact with other people, can transmit the bacteria.

b. Risk factors for Escherichia Coli

Anyone can get an E. coli bacterial infection. However, there are several factors that can increase a person's risk of developing a disease caused by E. coli, including:

- Age

Children, pregnant women, and the elderly are more prone to suffer from diseases caused by coli to suffer more serious complications.

- Weak immune system

Weak immune systems, such as those with AIDS and patients undergoing chemotherapy, are more susceptible to E. coli infections.

- Decreased stomach acid

Acid-lowering medications or stomach ulcers, such as esomeprazole, pantoprazole, lansoprazole, and omeprazole have the potential to increase the risk of E. coli infection.

c. Symptoms of Escherichia Coli Infection

The symptoms of E. coli infection are different for each person. However, this infection is often with diarrhea. Generally, these symptoms are felt since 3-4 days after exposure to bacteria. Aside from diarrhea, symptoms of E.Coli infection can be:

- Severe abdominal pain to cramps

- Nausea and vomiting

- Bloated

- Loss of appetite

- Fever

- Shivering

- Dizzy

- Muscle ache

d. Complications due to Escherichia Coli

A small proportion of patients with E. coli type STEC can be affected by complications of Uremic Hemolytic Syndrome (HUS). This condition is caused by toxins from the E. coli bacteria. The poison is then passed into a vein and sent to white blood cells to the kidneys. As a result, sufferers can experience acute kidney failure, pancreatitis, seizures, and coma. This complication is more common in children aged 1-10 years and the elderly, compared to adults.

e. Prevention of E. coli infections

Application of a clean lifestyle to prevent dangerous Escherichia coli infections. Here are some ways that you can do everyday:

- Wash hands immediately after leaving the bathroom and after changing a child's diaper.

- Wash hands before and after preparing food. 
- Wash hands after touching animals or working in an environment with many animals, such as in a zoo or a farm.

- Make sure items that will touch the mouths of infants and toddlers, such as pacifiers and teether, are clean.

- If there is no water and soap, use a hand sanitizer that contains alcohol at least $60 \%$, to reduce germs on the hands.

- Cook meat until cooked and wash all used cooking utensils, to prevent exposure to harmful E. coli bacteria from food.

\subsection{Medan City Government Policies Regarding Urban Settlement Development}

In accordance with the mandate of Law No. 1 of 2011 concerning the Development of Settlement Areas, it can be stated that:

a. Mandate related to Settlement of Housing and Slums is:

1. The implementation of the development of urban residential environment in article 59 includes:

a. Prevention of the growth of slums and slums

b. Prevention of growth and development of residential environments that are not planned and irregular.

2. Planning for the development of urban residential environments in article 66 includes:

a. Preparation of plans to prevent the growth of slums and slums

b. Preparation of prevention plans for the growth and development of unplanned and irregular residential environments.

3. Control of residential areas is the responsibility of the government and regional governments. Control of residential areas is intended to:

a. Preventing the growth and development of slums and slums;

b. Preventing the growth and development of unplanned and irregular residential environments.

b. Prevention and improvement of the quality of slums and slums contained in article 94 with the aim of:

a. Improving the quality of life and livelihoods of residents;

b. Preventing the growth and development of slums and new slums;

c. Maintain and improve the quality and function of housing and settlements.

The principle of certainty of residence which guarantees the right of every citizen to occupy, enjoy, and / or own a residence in accordance with statutory provisions.

c. Prevention (Law No. 1 of 2011 Article 95)

1. Efforts to prevent the growth and development of slums and new slums include:

- Irregularity and high building density;

- Incompleteness of public infrastructure, facilities and utilities;

- Declining quality of houses, housing and settlements as well as public infrastructure, facilities and utilities;

- Construction of houses, housing and settlements that are not in accordance with the regional spatial plan.

2. Implementation of prevention through:

- Supervision and control of conformity:

- Licensing

- Technical Standards

- Eligibility of functions through periodic checks in accordance with statutory regulations. 
- Community empowerment is carried out for stakeholders in housing and settlement areas through assistance and information services.

Slum prevention must be done by the government, local government and / or everyone. Further provisions regarding preventing the growth and development of slums and new slums are regulated by government regulations.

d. Quality improvement

Patterns of handling in improving the quality of slums and slums:

a. Restoration

b. Plastering

c. Resettlement

d. Management

Determination of location in order to improve the quality of slums and slums is determined with the following requirements:

a. Compliance with National, Provincial and city / district spatial planning;

b. Compliance with building and environmental planning;

c. Conditions and quality of infrastructure and public utilities that meet the requirements and do not endanger the occupants;

d. The level of regularity and density of the building;

e. Building quality

f. Socio-economic conditions of the local community.

Determination of the location of slums and slums must be preceded by the data collection process carried out by the local government by involving the community. The location determination is carried out by the regional government with regional regulations. The requirements and procedures for determining the location, renovation, rejuvenation, resettlement and management of quality improvement of slums and slums are regulated by government regulations.

In accordance with Law Number 32 of 2004 concerning Regional Government, the functions and important roles of the City Government are as entrepreneurs, coordinators, facilitators and stimulators for the emergence of creativity, innovation and various elements of city development to develop Medan City as a Modern, Madani Metropolitan City and Religious in the medium term and / or Medan City which is Advanced, Prosperous, just and religious in the long term.

Considering the very strategic position, function and role of the City Government, the implementation of the City Government's general governance is directed to develop employment opportunities and achieve regional economic stability, therefore urban development requires systematic, directed, integrated, comprehensive and anticipatory planning.

\subsection{General Description of Hamdan Village}

Geographically, Hamdan Village is located at coordinates 2027 '- 20 47' LU and 980 35 '- 980 44' BT. the administrative boundaries of the Hamdan sub-district of Medan Maimun Medan City are as follows.

- North side is bordered by Kelurahan Sekip

- South side is bordered by Madras Hulu Village

- West side is bordered by Kelurahan Sei Sikambing D

- East side is bordered by Kesawan Village

Hamdan Village has a minimum temperature range of $23.0^{\circ} \mathrm{C}-24.1^{\circ} \mathrm{C}$ and a maximum temperature ranging from $30.6^{\circ} \mathrm{C}-33.1^{\circ} \mathrm{C}$. The average humidity in the city of Medan ranges from 78 to $82 \%$. An average wind speed of $0.42 \mathrm{~m} / \mathrm{sec}$ with an average total 
evaporation rate per month of $100.6 \mathrm{~mm}$. Average rainfall ranges from $211.67 \mathrm{~mm}-230.3$ $\mathrm{mm}$. This village has an area of 52 ha which is divided into 10 neighborhoods.

\subsection{Deli River}

DAS (Watershed) Deli is a Watershed in North Sumatra Province with an area of 47,298.01 Ha. The Deli Watershed stretches between $3^{\circ} 13$ '35.50' 'to $3^{\circ} 47^{\prime} 06.05$ " North Latitude and meridians $98^{\circ} 29$ '22.52' 'to $98^{\circ} 42^{\prime}$ 51, 23 " East Longitude. Administratively the Deli DAS is located in 3 (three) Regencies namely Karo Regency covering an area of 1,417.65 Ha (3\%), Deli Serdang Regency covering 29,115.20 Ha (61.56\%) and Medan City covering 16,765.16 ha (35.45\%). The Deli watershed border is bordered by; The North is bordered by the Belawan River Basin; The South is bordered by the Wampu River Basin; The West is bordered by the Belawan River Basin; The East is bordered by the Batang Kuis River Basin. Based on the analysis of Geographic Information Systems and Field Checks, Deli DAS is divided into 7 (seven) Sub Watersheds with the following details:

Table 2. Size of Sub Watershed in Deli Watershed by Administrative Region

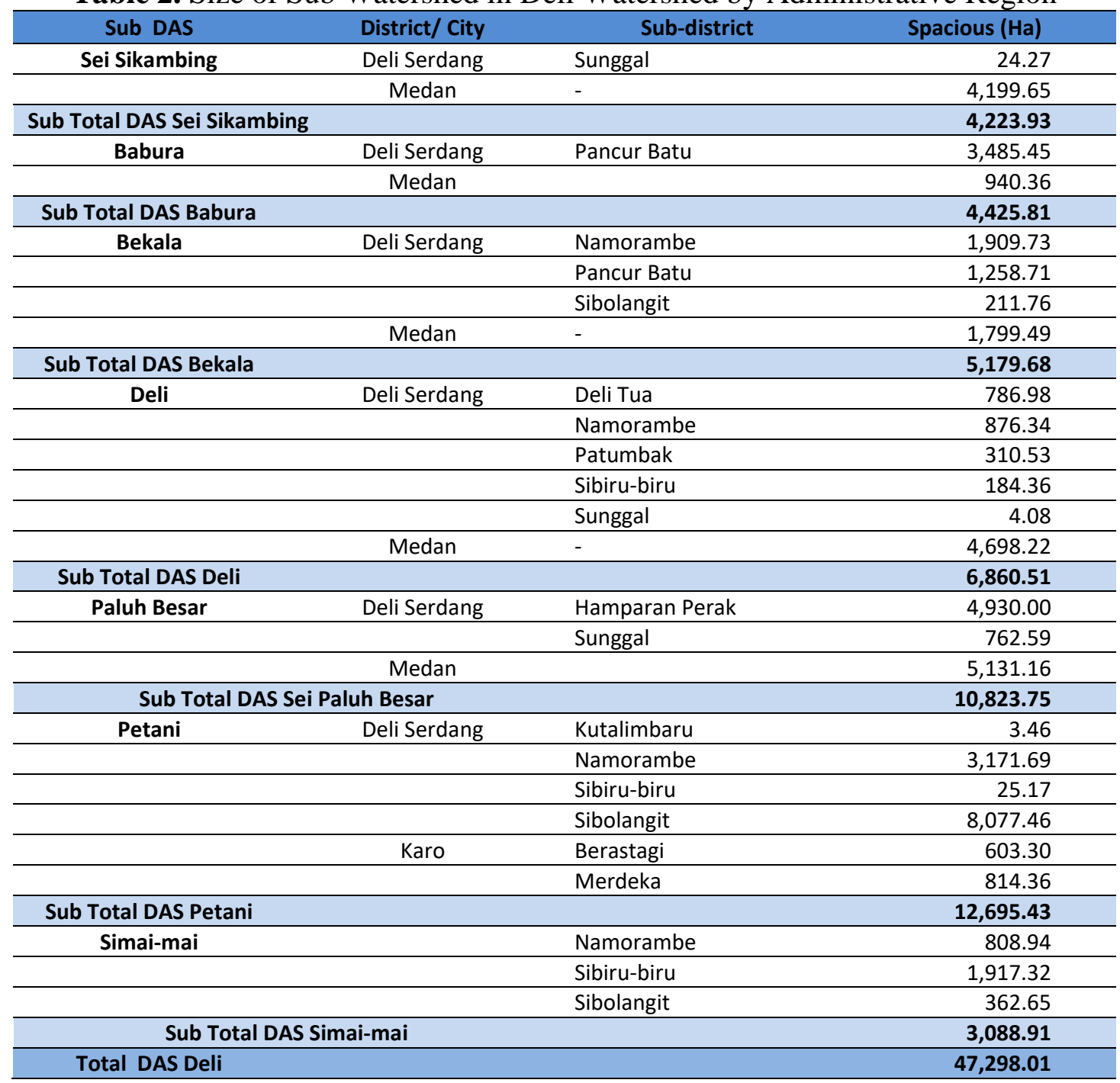

Source : Data, 2018 


\section{Research Method}

The research site is located in Hamdan Village t at coordinates 2027 '- 20 47' 'LU and $98035^{\prime}$ - 98044 'BT. the administrative boundaries of the Hamdan sub-district of Medan Maimun Medan City are as follows.

- North side is bordered by Kelurahan Sekip

- South side is bordered by Madras Hulu Village

- West side is bordered by Kelurahan Sei Sikambing D

- East side is bordered by Kesawan Village

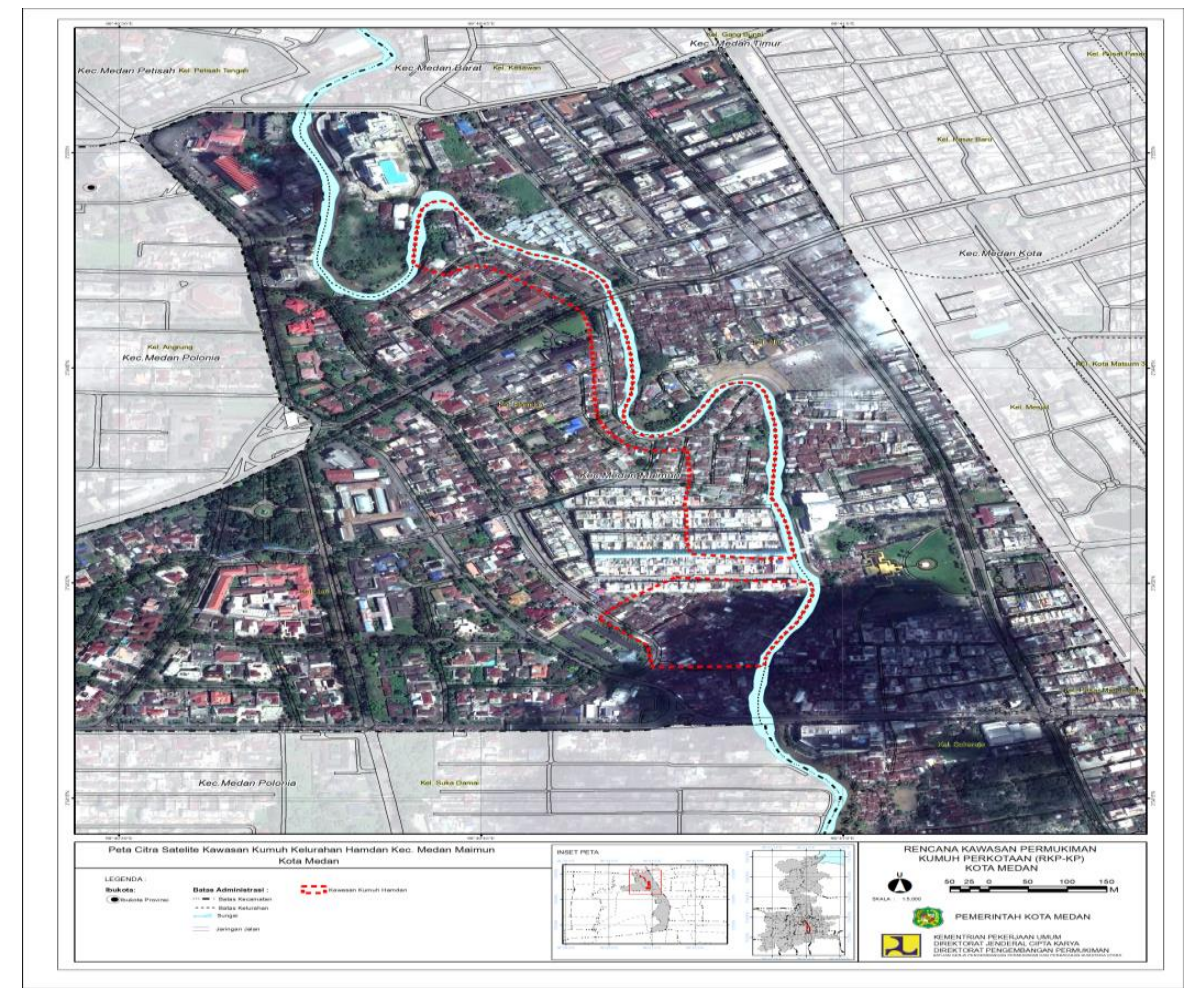

Figure 1. Research Location

When the study was conducted for 1 (one) year consisting of

A. The first 4 (four) months of sampling and analyzing pollutant load

B. The second 4 (four) months annexed the Waste Management in Hamdan Urban Village C. 4 (Four) months Third report writing

\subsection{Observed Parameters}

The parameter observed was the E. Coli pollutant load using the standard Minister of the Environment Regulation No. 110/2003 on guidelines for determining the capacity of the pollutant load on water sources.

\subsection{Data Collection Technique}

The technique used is:

A. Direct observation on the Deli River that is adjacent to Hamdan Village Related to the infrastructure of Hamdan Village waste treatment facilities

B. Sampling Pollutant Load E. Coli

C. Conducting Waste Analysis for Hamdan Urban Village 


\subsection{Data analysis method}

a. Primary Data

a. Biological water sampling E. Colli according to pollutant load Permenlh No 110 th 2003 concerning guidelines for determining the capacity of water pollutant load at water sources

b. Determination of infrastructure slum areas based on Law Number 1 of 2011 concerning Housing and Settlement Areas

c. Deliniation of slums kel. Hamdan

d. Documentation

b. Secondary Data

a. Deli River Basin Distribution along Ex. Hamdan

b. Administrative Region Kel. Hamdan

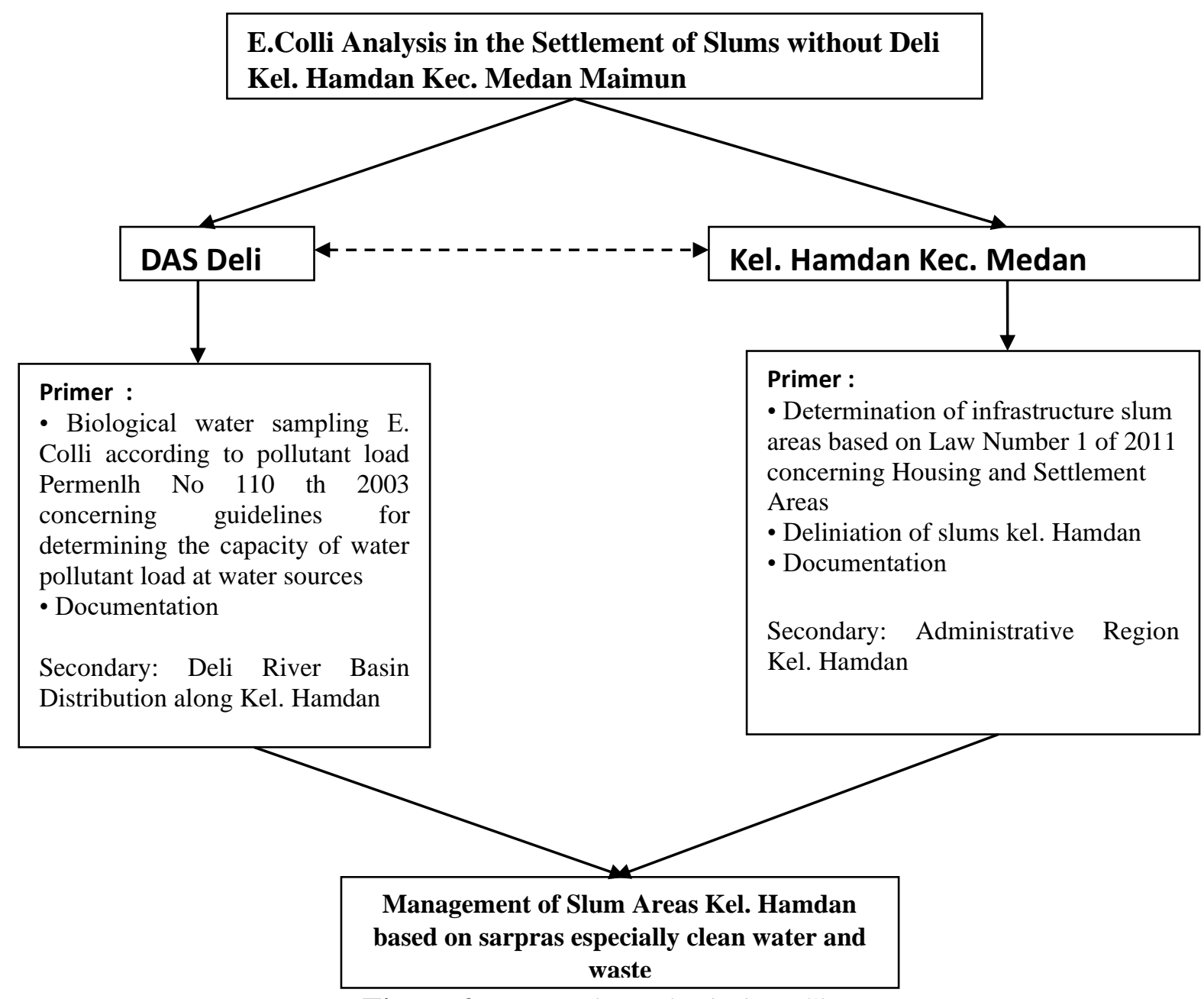

Figure 2. Research Method Flow Chart

\section{Discussion}

Water samples were taken at three points namely Avros Park, Jl. Ir. Juanda (right under the very meatballs) and Kampung Aur with coordinate points can be seen in the following figure. The method of taking water by taking water placed in a sterile bottle. 


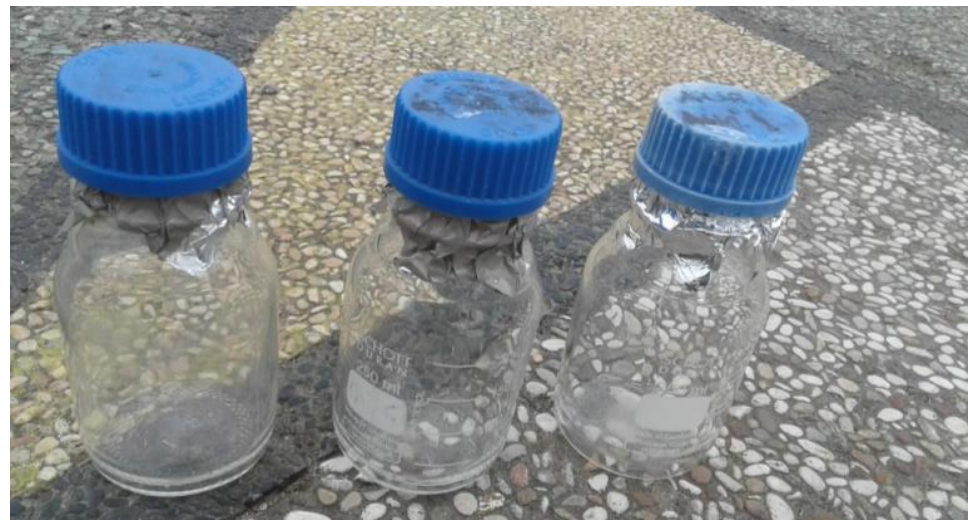

Figure 3. Sterile Bottle
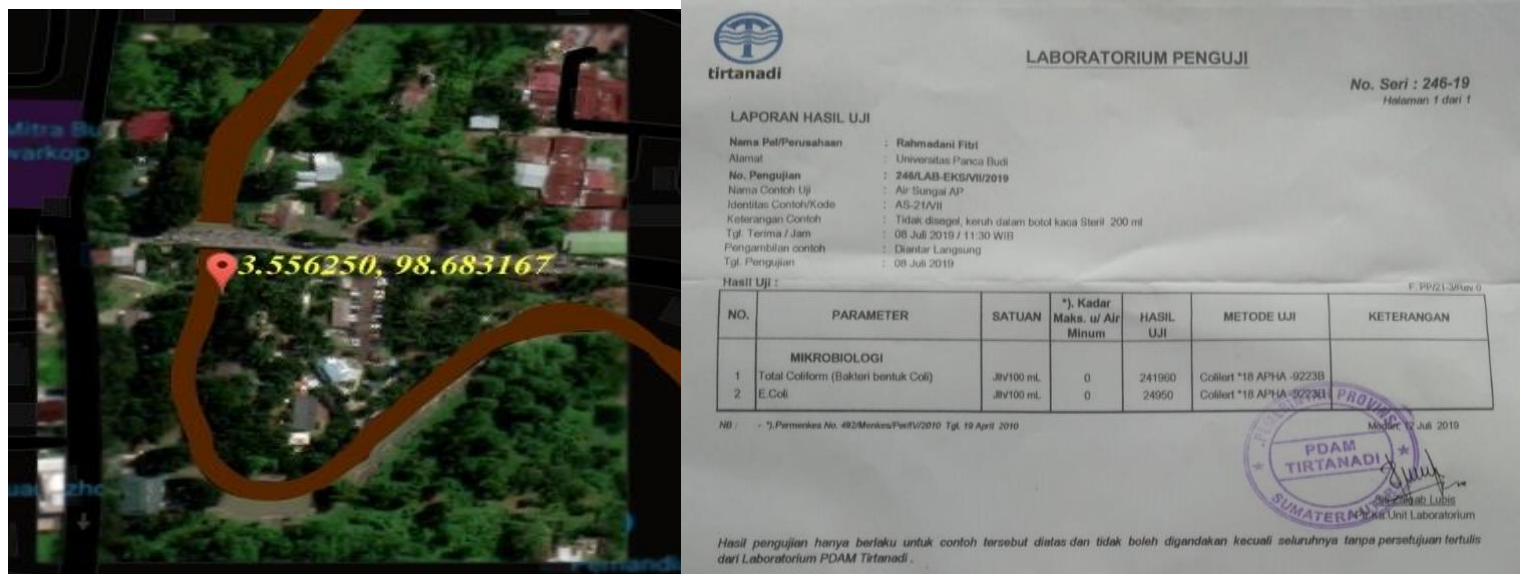

Figure 4. Location of Sampling and Analysis Results at Avros Park
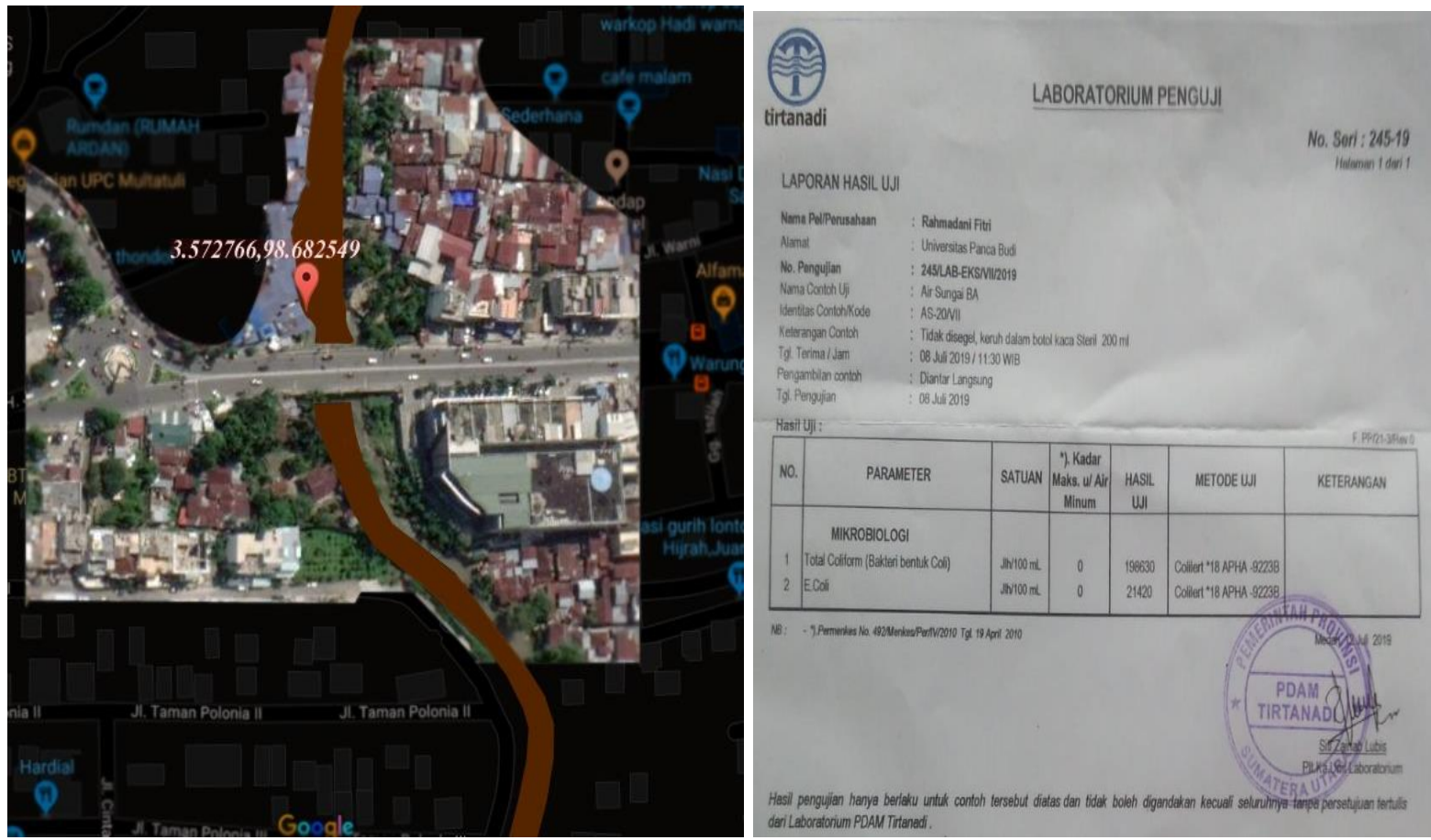

Figure 5. Sampling Location and Analysis Results in Ir. Juanda (Amat Meatballs) 

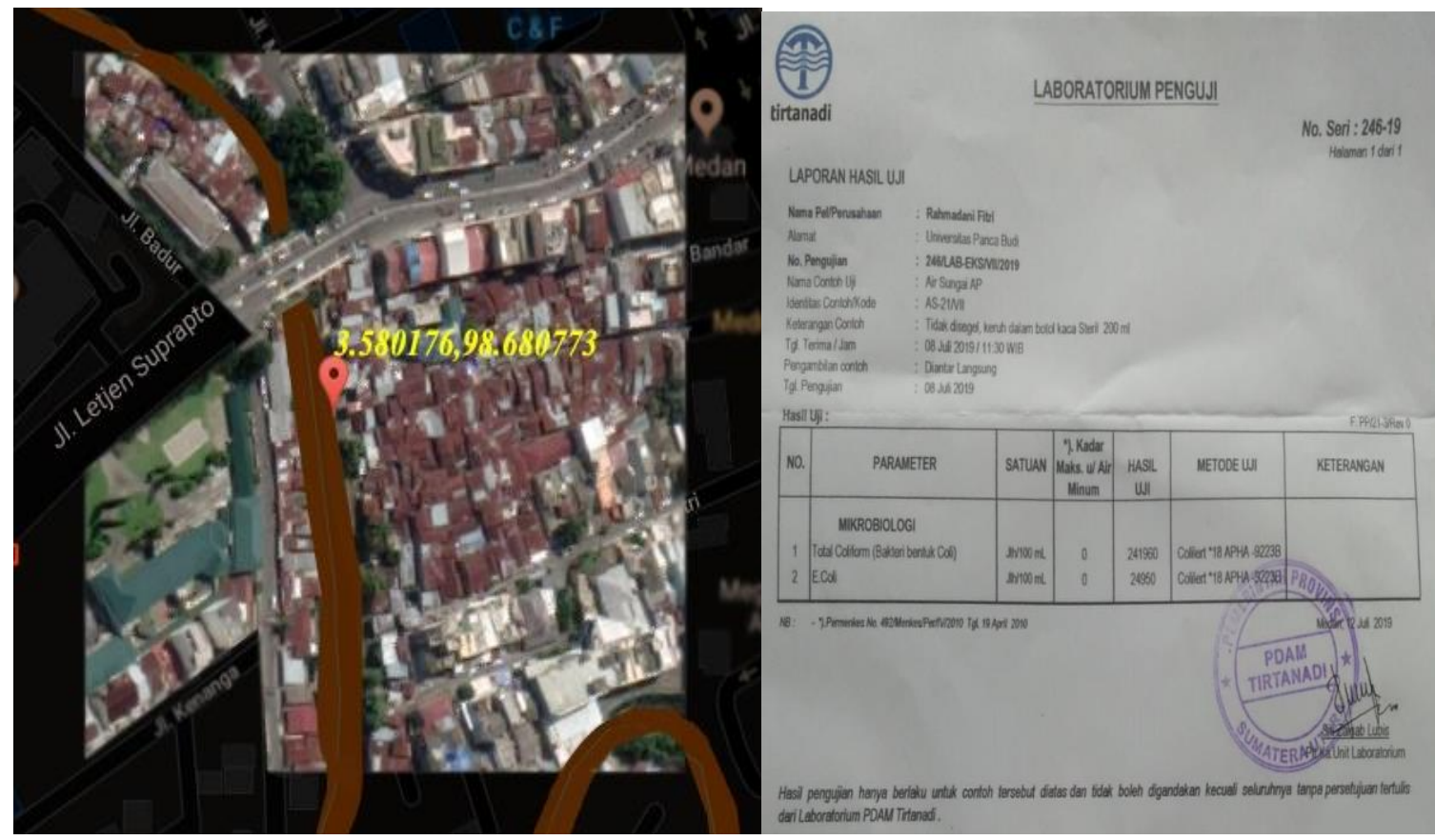

Figure 6. Sampling Location and Analysis Results in Kampung Aur The research results can be seen in the following table.

Table 3. E.Colli Analysis Results

\begin{tabular}{|c|r|c|c|c|}
\hline \multirow{2}{*}{ Location } & \multicolumn{2}{|c|}{ E.Colli (Jlh / 100ml) } & \multicolumn{2}{c|}{ Total Coliform (Jlh / 100ml) } \\
\cline { 2 - 5 } & Analysis & Maximum levels & Analysis & Maximum levels \\
\hline Avros Park & 24950 & 0 & 241960 & 0 \\
\hline Ir. Juanda & 21420 & 0 & 198630 & 0 \\
\hline Kampung Aur & 36540 & 0 & $>241960$ & 0 \\
\hline
\end{tabular}

Source: Laboratory Analysis Results of PDAM Tirtanadi Medan

The table above can be concluded that E. Colli and Total Coliform are above the established quality standards, therefore it is necessary to treat water before spatial planning. One of the requirements for clean water quality is biological factors, namely E. colli and Total coliform bacteria.

Alternative water treatment needs to be done before structuring buildings around the river location. AWWA, 1998 states that if the bacterial quality standard above the specified quality standard is by processing filtration and disinfecting. The arrangement that needs to be done next is to make a bathroom around the river location. E. Colli, which is identical, comes from fecal matter, so there is a need for public bathrooms around the river. This is done to save the quality of river water. The existence of a public bathroom into an organized arrangement of sewage. E. coli cannot be killed by cooling or freezing, this bacterium can only be killed by antibiotics, Ultraviolet (UV) sinau, or high temperatures $>1000 \mathrm{C}$. High temperatures will damage the protein in cells and make it unable to live again. Nongenetically engineered (wild type) E. coli generally cannot survive if there are antibiotics such as amphicillin and chloramphenicol (Girard et al., 2003) even with antibiotics such as Amoxicillin are sufficient (derivatives of amphicillin which have lower killing power). In general, these bacteria can be found in the human large intestine. Most E. Coli are harmless, but some like E. Coli type O157: H7 can cause serious food poisoning in humans, namely 
bloody diarrhea due to the exotoxin produced called verotoxin. Disinfection is a water treatment process to kill pathogenic bacteria using disinfectants. Affixing the disinfectant is usually done after the filtration unit and it takes a sachlor chloride of 0.2-0.5 mg / 1 thereafter to be distributed to the distribution network (PP No. 82 of 2001). Some types of disinfectants that are often used in the process of removing microorganisms, namely ozone, ultraviolet radiation and chlorination. However, a disinfectant that is commonly used in Indonesia is calcium hypochlorite $[\mathrm{Ca}(\mathrm{ClO}) 2]$ or chlorine, because the price is relatively cheap, is stable and can be stored longer (Said, 1999). DBP is a chlorine reaction with organic compounds contained in raw water, DBP can cause cell damage and is carcinogenic, so it is necessary to determine the right disinfectant dose so that the disinfected water is free of DBP (Rice, 2009). The effectiveness of disinfection can be influenced by the presence of other compounds, including ammonia, nitrites and nitrates. This compound can reduce chlorine disinfectant performance because d-synfectant will react first with ammonia and nitrate before the disinfection process with bacteria (Metcalf and Eddy, 2007).

The number of bacteria in ground water (well water) in Indonesia varies considerably between 5 to $1000 \mathrm{MPN} / 100 \mathrm{ml}$. 10,000 MPN / $100 \mathrm{ml}$ exceeds the number of bacteria found in the gutter. The dirty water will smell and also cannot be used for bathing. For comparison, 10 thousand MPN per $100 \mathrm{ml}$ is equal to 1000 human waste in one swimming pool. (http://oasisdesign.net/water/quality/coliform.htm). Water conditions polluted by E.coli can be treated with water to reduce levels. So that polluted water can be consumed.

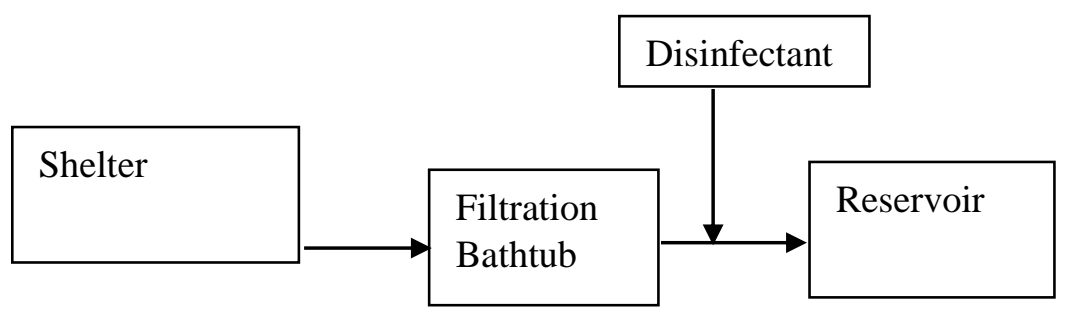

Figure 7. Water Treatment System

Pathogenic microorganisms in water can be phased out in drinking water treatment and enhanced. The number of bacteria in ground water (well water) in Indonesia varies considerably between 5 to 1000 MPN / 100ml. 10,000 MPN / $100 \mathrm{ml}$ exceeds the number of bacteria found in the gutter. The dirty water will smell and also cannot be used for bathing. For comparison, 10 thousand MPN per $100 \mathrm{ml}$ is equal to 1000 human waste in one swimming pool. (http://oasisdesign.net/water/quality/coliform.htm). Water conditions polluted by E.coli can be treated with water to reduce levels. So that polluted water can be consumed. by disinfection process (Tchobanoglous, 2003). Disinfection is a water treatment process to kill pathogenic bacteria using disinfectants. Water purification of this water purifier goes through 4 stages namely: micro fiber filter, activated carbon filter, germ killer processor and purifier. Micro fiber filter works to remove visible impurities. Micro fiber filters can filter out coarse particles that can be seen by the eye up to $0.1 \mathrm{~mm}$ in size. E. micoli diameters 0.5 micrometers so with a larger micro fiber size can not inhibit E. coli. So E.coli still contaminates water.

To reduce E.Colli polluted in river water, public facilities are needed, including public bathrooms. Bathroom activities are adjusted to the activities of bathing, washing and toilet (MCK). The bathroom is made based on gender, male and female. 


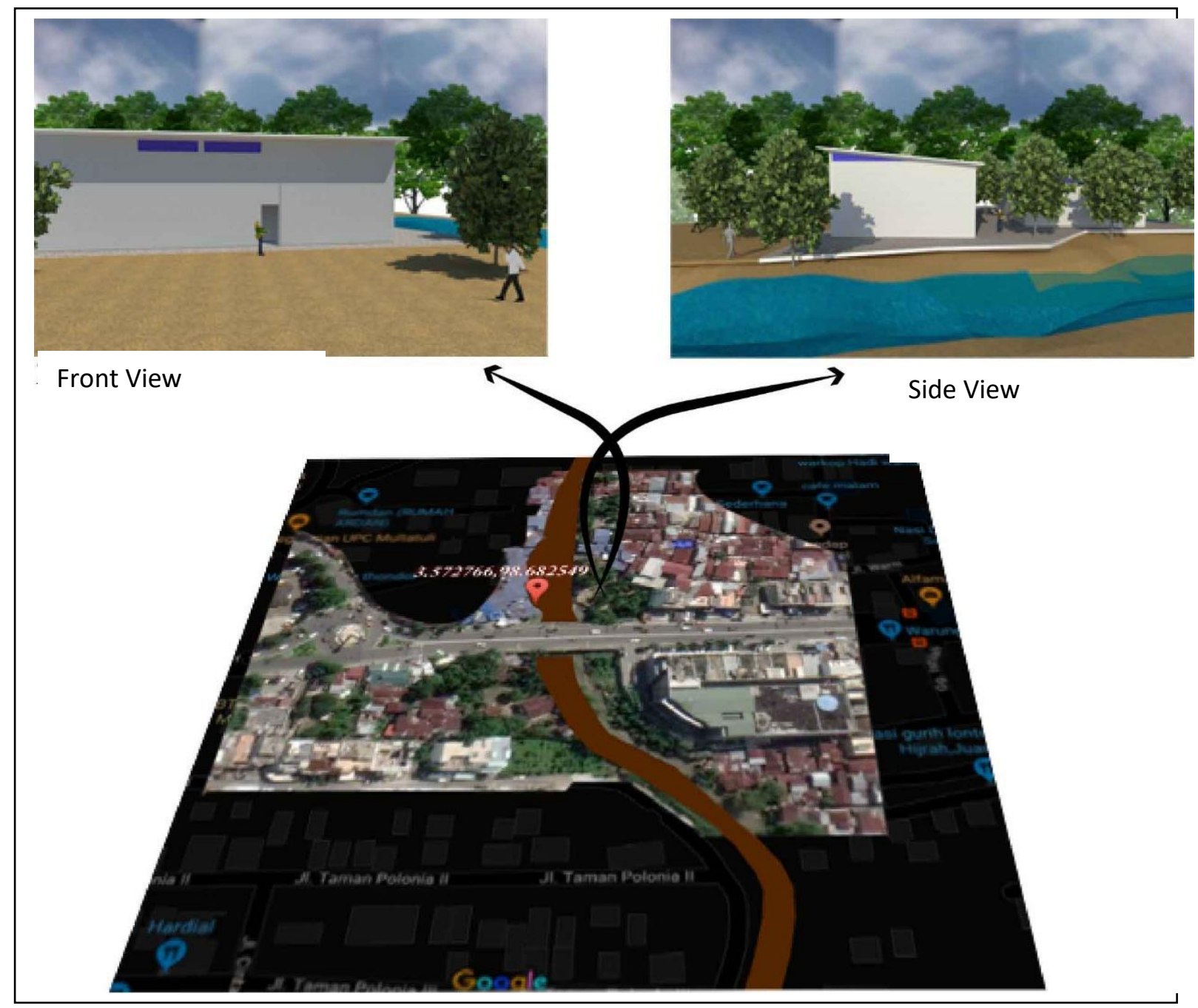

Figure 8. Planning a Public Bathroom around the Ir Juanda River

The location of the bathroom is placed close to the river to facilitate drainage of clean water and dirty water. Freeing up bathing activities required a large tub. Another tub is also needed for washing activities.

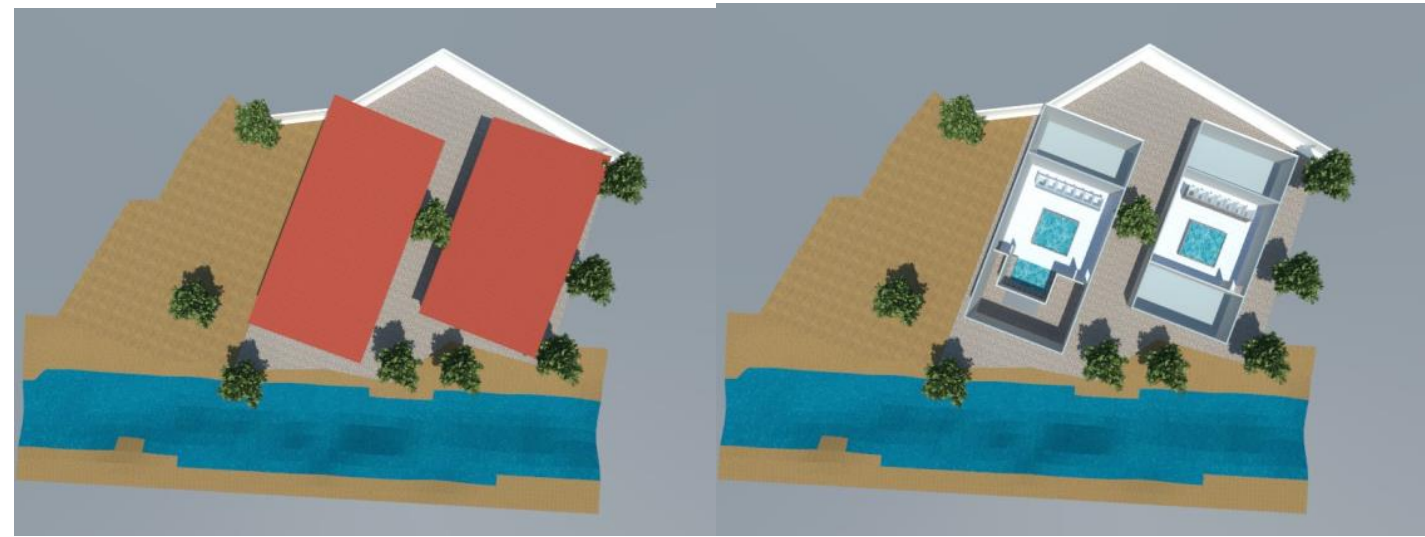

Figure 9. Men and Women Public Bathroom Planning 
The design of the arrangement of clean water and wastewater is needed to reduce the incidence of water pollution due to E. Colli. The position of water treatment is placed close to the river, while the position of waste after bathroom activities takes place.

\section{Conclusion}

The conclusions of this study are:

1. Analysis results of E. Colli Laboratory amounting to $21420-36540 / 100 \mathrm{ml}$, still above the quality standards set by PP No.82 of 2001 concerning the management of water quality and control of water pollution.

2. The results of the analysis of Total Coliform Laboratory of $198630-241960 / 100 \mathrm{ml}$, are still above the quality standards set by PP No.82 of 2001 concerning the management of water quality and control of water pollution.

3. Alternative water treatment needs to be done before structuring buildings around the river location by means of filtration treatment and disinfecting.

4. The arrangement that needs to be done next is to make a bathroom around the river location.

\section{References}

Al - Layla M. Anis, 1978. Water Supply Engineering Design. Ann Arbor Science Publisher Inc, Michigan.

Alaerts, G., Santika. 1984. Metoda Penelitian Air. Usaha Nasional. Surabaya.

Anonim 2001. Peraturan Pemerintah No. 82 Tahun 2001 Tanggal 14 Desember 2001 Tentang Pengelolaan Kualitas Air dan Pengendalian Pencemaran Air.

Anonim, 2002. Keputusan Menteri Kesehatan Republik Indonesia No. 907 / MENKES/ SK/ VII/ 2002.

Asan Alolo, 1998. Proses Pengolahan PDAM Tirtanadi Medan. PDAM Tirtanadi Medan. Medan.

Asdak, C.1999. Hidrologi dan Pengelolaan Daerah Aliran Sungai. Gadjah Mada University Press. Yogyakarta.

AWWA, 1998. Water Treatment Plant Design Fourth Edition. Mcgraw Hill International Edition, Singapore.

Cheremisinoff, N. Paul, 1995. Handbook Water and Wastewater Treatment Technology. New Jersey Institute of Technology. New York.

Darmasetiawan Martin, 2004. Instalasi Pengolahan Air. Ekamitra Engineering, Jakarta.

Effendi E. 2008. Kajian Model Pengelolaan Daerah Aliran Sungai (DAS) Terpadu.Direktorat Kehutanan dan Konservasi Sumberdaya Air, Badan Perencanaan Pembangunan Nasional.Jakarta.

Effendi, H.2003.Telaah Kualitas Air Bagi Pengelolaan Sumber Daya dan Lingkungan Perairan. Kanisius.Yogyakarta.

Kalsim Kusnadi Desi, 2001. Irigasi Pompa. Teknik Tanah Air. Fakultas Teknik Pertanian. Institut Pertanian Bogor. Bogor.

Kawamura Susumu, 1991. Integrated Design of Water Treatmen Facilities. Interscience Publication. New York.

Kepmenkes) RI No. 907/Menkes/SK/VII/2002 Tentang Syarat-syarat dan Pengawas Kualitas

Air Minum menyebutkan bahwa air minum

Lies Indah Sutiknowati . Bioindikator Pencemar, Bakteri Escherichia Coli. Oseana, Volume XLI, Nomor 4 Tahun 2016 : 63 - 71 ISSN 0216-1877 
Lubis Zulkifli, 2008. Proses Pengolahan air PDAM Tirtanadi Medan. PDAM Tirtanadi Medan. Medan.

Menteri Negara Lingkungan Hidup. 2003. Keputusan Menteri Negara Lingkungan Hidup Nomor: 115 Tahun 2003 Tentang Pedoman Penentuan Status Mutu Air. Kementrian Lingkungan Hidup. Jakarta.

Mochtar, H dan Oktiawan, W. 2005. Bahan Ajar Satuan Operasi/ Jurusan Teknik Lingkungan Universitas Diponegoro. Semarang.

Montgomery, 1985. Water Treatment Principles and Design. Interscience Publication. New York.

Nasrullah dan Oktiawan, W. 2005. Perencanaan Bangunan Pengolahan Air Minum. Jurusan Teknik Lingkungan Universitas Diponegoro. Semarang.

Peavy Howard S, G. Tchobanoglous, 1985. Environmental Engineering. Mcgraw Hill International Edition, Singapore.

Puti Sri Komala, Feni Agustina. Pengaruh Pengganggu Pada Proses Disinfeksi Terhadap Penyisihan Bakteri Escherichia coli pada Air Pengolahan PDAM Gunung Pangilun. Prosiding SNTK Topi 201. ISSN. 1907 - 0500

Reynolds, T. D. 1982. Unit Operations In Environmental Engineering. Texas A \& $\mathrm{M}$ University; B /C Engineering Division Boston, Massacusetts.

Rice, G. E., L. K., Teuschler, R. J.,Bull, J. E.,Simmons, dan P. 1., Feder. 2009. Evaluating the similarity of complex drinkingwater disinfection by-product mixtures:Overview of the issuesJ Toxicol. Environ. Health Part A 72:429-436.

Said.T. N., dan D. H., Wahyono, 1999. Teknologi Pengolahan Air Limbah Rumah Sakit dengan Teknik Biofilter Aerob-anaerob. Jakarta: Direktorat Teknologi Lingkungan. Deputi Bidang Teknologi Informasi, Energi, Material dan Lingkungan- BPPT.

Undang - Undang No.1 Tahun 2011 tentang Pengembangan Kawasan Permukiman. 